\title{
STUDY OF SERUM PROTEIN, ALBUMIN, GLOBULIN AND ALBUMIN/GLOBULIN RATIO IN RELATION WITH HIV PATIENTS
}

\author{
Sujit Kumar Bhattacharyya1, Sukharanjan Howlader', Sumitra Basu Thakur ${ }^{3}$
}

${ }^{1}$ Associate Professor, Department of Respiratory Medicine, North Bengal Medical College, West Bengal, India.

${ }_{2}^{2}$ Associate Professor, Department of Radiodiagnosis, North Bengal Medical College, West Bengal, India.

${ }^{3}$ Professor and HOD, Department of Respiratory Medicine, Calcutta Medical College, West Bengal, India.

ABSTRACT
BACKGROUND
Human Immunodeficiency Virus Infection (HIV) is gradually becoming a threat to our society. It affects our immune system.
Proteins are important components of immune system. Notably albumin and globulin are chief components, which have important
impact not only on our nutrition but also on immunity. Study of serum protein and serum albumin and globulin ratio denotes
nutritional status of human beings. Their evaluation gives diagnostic and prognostic information, especially in relation to CD4
count.

The aim of this study is to assess the protein status of HIV positive patients, thereby their nutritional status and prognostic correlation with CD4 count.

\section{MATERIALS AND METHODS}

It was a descriptive analytical study done over 60 patients who were HIV positive attending indoor and outdoor of Department of Chest Medicine in a Tertiary Medical College in Kolkata, West Bengal, during the period of 2014 - 16. Patients with comorbidities like diabetes mellitus and renal diseases were excluded from our study. Serum total protein, albumin, globulin and albumin/globulin ratio were estimated and inserted in Microsoft Excel and thus calculation was performed.

\section{RESULTS}

HIV infection whether asymptomatic or symptomatic alters plasma level of total protein, albumin, globulin and albumin: globulin ratio. Serum protein was high, average albumin level decreased, average globulin level increased and A: G ratio reversed. In low CD4 count Albumin: Globulin ratio alteration is more evident as compared to high CD4 group. Association between CD4 counts and albumin/globulin ratio was calculated using Chi-square statistic. A p-value of less than 0.05 was considered statistically significant.

\section{CONCLUSION}

Serum protein increases with HIV progression and therefore can be used as a biomarker in the assessment of the progress of infection and has prognostic importance in relation with CD4 count.

\section{KEY WORDS}

Serum Proteins, HIV, Albumin, Globulin, Albumin: Globulin Ratio.

HOW TO CITE THIS ARTICLE: Bhattacharyya SK, Howlader S, Thakur SB. Study of serum protein, albumin, globulin and albumin/globulin ratio in relation with HIV patients. J. Evolution Med. Dent. Sci. 2018;7(37):4118-4121, DOI: $10.14260 /$ jemds/2018/921

\section{BACKGROUND}

Human Immunodeficiency Virus (HIV) produce a major threat amongst human populations. Many continents like Africa, South-East Asia and Europe face major challenges against this virus. In Asia especially, India because of big population is not free from this threat. As a consequence of HIV infection, many patients die of Acquired Immunodeficiency Syndrome (AIDS) and malnutrition. Human Immunodeficiency Virus (HIV) infection produces a slow, but progressive and lethal immune suppression with multisystem involvement which can lead to multiple opportunistic infections, neurological disorders and malignancies. This results from progressive depletion of the CD4 subset in helper/ inducer cells of T-lymphocyte,

'Financial or Other Competing Interest': None.

Submission 22-07-2018, Peer Review 25-08-2018,

Acceptance 31-08-2018, Published 10-09-2018.

Corresponding Author:

Dr. Sukharanjan Howlader,

C/o. Dr. S. K. Bhattacharyya,

Vill Aminpur, PO Khamarchandi,

PS: Haripal District, Hooghly-712405,

West Bengal, India.

E-mail: drsujit.haripal@yahoo.in

DOI: $10.14260 /$ jemds/2018/921

\section{(c) $(1) \ominus$}

monocyte and macrophages. Ultimately, the disease progress to Acquired Immunodeficiency Syndrome (AIDS), the terminal phase of the disease.

Many factors contribute to malnutrition in HIV like decreased food intake and disturbance in digestion. HIV infection is associated with typical metabolic disorder. Abnormalities in metabolism of glucose, lipid, protein and effect of opportunistic infection and altered host immune response takes part in disturbance of nutrition. Protein which is made up of many chains of polypeptides having many functions in the body including immune systems. Deficiency of protein and its amino acid components as well as vitamins are associated with reduced immune systems. Dysproteinaemic syndromes found frequently in clinical practice and determination of various fractions of proteins found in plasma may help in diagnosis and management of various diseases. Over production of immunoglobulins due to polyclonal B cell activation is observed early in the course of HIV infection. ${ }^{1}$ The polyclonal B cell activation is due to viral envelope protein, especially glycoprotein 41 to produce excess abnormal immunoglobulins. ${ }^{2}$ Diarrhoea is a common presenting feature of AIDS. Many patients with HIV who develop diarrhoea have some degree of jejunal villous atrophy and over $70 \%$ have some evidence of malabsorption. 
Plasma viral load and CD4 T-cell counts in conjunction with the patient's clinical status are presently the gold standards of assessing and monitoring the clinical progression in HIV infection. However, the routine use of these parameters in developed countries is limited because of high cost, poor availability of required technology and trained personnel. ${ }^{3}$ Other surrogate markers have been used for monitoring the progression of HIV infection and assessing response to therapy. These include CD38, HLA-DR, IL-2R and CD45RO. However, again a common problem in terms of its cost which hinders its use beyond its reach to poorer nation. ${ }^{4}$

Plasma proteins have fractions like albumin and globulin. Albumin is a small globular protein with molecular mass weight $66.3 \mathrm{kDa}$. It has most abundant proteins and has no carbohydrate side chain, but is highly soluble in water due to high negative charges at PH 7.4. Albumin are synthesised by hepatic parenchymal cells. It functions mainly for maintaining colloidal osmotic pressure and also serve for transporting of large compounds like free fatty acid, amino acid and many important drugs. ${ }^{5}$ Total serum protein usually has normal value of 6 - 8 gms/dL. Normal range of albumin is $3.2-4.5$ $\mathrm{gms} / \mathrm{dL}$ and globulin ranges from $2.3-4.5 \mathrm{gms} / \mathrm{dL}$.

\section{Objective}

To assess the protein status of HIV positive patients and to find the association between CD4 counts and the albuminglobulin ratio.

\section{MATERIALS AND METHODS}

This was a descriptive cross-sectional study. Consecutive patients attending the indoor and outdoor of the Chest Department of a Tertiary Medical College in Kolkata, West Bengal, during the period 2014 - 2016 were included in the study. Patients with diabetes and renal diseases were excluded.

All patients who were enrolled were tested with serum albumin, globulin and A:G ratio and a CD4 count done. Five millilitre of venous blood was collected aseptically into a plain container and allowed to clot. This was spun at 3000 rpm for 10 mins to obtain a clear serum, which is kept frozen until required for analysis.

Total serum protein and albumin was determined by spectrophotometry using Biuret and Bromocresol green methods respectively. Serum globulin was calculated by subtracting albumin and total protein. A:G ratio was calculated by dividing albumin and globulin.

Data was entered into predesigned schedule and checked for consistency and completeness. Thereafter, data was inserted into Microsoft Excel and calculations performed.

\section{Statistical Analysis}

Statistical analysis was done using IBM SPSS (Version 19). The results were analysed and presented using principles of descriptive and analytical statistics. Comparative analysis with association between CD4 counts and the albumin globulin ratio was calculated using the Chi-square statistic. A p-value of less than 0.05 was considered statistically significant.

\section{RESULTS}

Total 60 HIV positive patients were included in our study. Males outnumbered females with the ratio of $4: 1$ (48 male:
12 female). Most of the patients come from lower economical background as evident from their profession like labourers 15 (25\%), drivers 12 (20\%), hawkers 15 (25\%), victims 12 $(20 \%)$ and all are females affected by their sexual partner, other group contributes $6(10 \%)$ who are all affected from accidental blood transfusion. Average total protein was estimated $7.48 \mathrm{gm} \%$. Average albumin was $3.64 \mathrm{gm} \%$, whereas average globulin was $3.84 \%$. Out of 60 cases albumin: globulin ratio was found more than 1 in 27 patients (45\%), which varied ranges from 1.03 to 1.78 . Contrary Albumin: Globulin ratio was found to be less than 1 in 33 patients (55\%), which varied from 0.59 to 0.98 . All results were compared with CD4 count. In our study 15 patients' (25\%) CD4 count was less than 200/cc and albumin: globulin ratio was markedly altered in majority. In this group with 12 patients' (20\%) A: G ratio was less than 1 and 3 patients' $(5 \%)$ ratio was more than 1 . In another group where 45 patients were found with CD4 count more than 200/cc, A: G ratio remained marginally raised in 24 patients (40\%) and rest of the patients' $(35 \%)$ ratio was found to be less than 1 .

There is a significant difference in the number of patients with altered albumin: globulin ratio in patients with lesser than and greater than $200 \mathrm{mg} / \mathrm{dL}$ CD4 count levels.

\begin{tabular}{|c|c|c|}
\hline Sex & Number & Percentage \\
\hline Male & 48 & $80 \%$ \\
\hline Female & 12 & $20 \%$ \\
\hline \multicolumn{2}{|c|}{ Table 1. Table showing the distribution of Sex in the Study } \\
Population (n= 60)
\end{tabular}

\begin{tabular}{|c|c|c|}
\hline Occupation & Number & Percentage \\
\hline Labourers & 15 & $25 \%$ \\
\hline Drivers & 12 & $20 \%$ \\
\hline Hawkers & 15 & $25 \%$ \\
\hline Victims & 12 & $20 \%$ \\
\hline Others & 6 & $10 \%$ \\
\hline \multicolumn{2}{|c|}{$\begin{array}{c}\text { Table 2. Table showing the distribution of in } \\
\text { the Study Population (n= 60) }\end{array}$} \\
\hline
\end{tabular}

\begin{tabular}{|c|c|c|c|c|}
\hline $\begin{array}{c}\text { CD4 Count } \\
\mathbf{2} \mathbf{2 0 0} / \mathbf{c c}\end{array}$ & \multicolumn{2}{|c|}{ A:G 1 } & \multirow{2}{*}{$\begin{array}{c}\text { Chi- } \\
\text { Square }\end{array}$} & \multirow{2}{*}{ P value } \\
\cline { 2 - 3 } Yes & $24(53.3)$ & $21(46.7)$ & \multirow{2}{*}{5.05} & \multirow{2}{*}{$0.04^{*}$} \\
\hline No & $3(20)$ & $12(80)$ & & \\
\hline Total & $\mathbf{2 7}(45)$ & $33(55)$ & & \\
\hline \multicolumn{6}{|c|}{ Table 3. Table showing the A/G Ratio in relation } \\
with CD4 Count (n= 60) \\
\hline
\end{tabular}

*Statistically Significant.

\section{DISCUSSION}

In our present study, mean serum total protein level was 7.48 gm\%, albumin level was 3.64/dL which was consistent with observation by $\mathrm{R}$ Patil et al study where it was found to be $7.43 \pm 0.43$ gm\%. ${ }^{6}$ Ullrich and associates observed serum protein for HIV positive patients to be $7.3 \mathrm{gms} / \mathrm{L}$ and serum albumin was $38 \mathrm{gm} / \mathrm{L}^{7}$ Serum globulin level was comparatively greater than albumin in our study $3.8 \mathrm{gm} / \mathrm{dL}$. The increase in the anion gap may be associated with increased level of IgG. Mehta et al observed serum albumin level was less than $35 \mathrm{~g} / \mathrm{L}$ and he also noted that hypoalbuminaemia as a pointer to faster progression of HIV to AIDS. The low albumin levels may be due to malnutrition or chronic inflammation associated with AIDS and HIV 
infection. This is because albumin is a negative acute phase reactive protein, whose levels can possibly be depressed by elevated levels of Tumour Necrosis Factor (TNF) and Interleukin-1 (IL-1) during chronic inflammation. ${ }^{8}$ Hyperglobulinaemia was also observed in other studies by Quesnel A. ${ }^{9}$ Similar observation of hyperglobulinaemia was observed by Ikekpeazu and his associates. ${ }^{10}$ Oluwaseun 0 et al described same findings of high globulin level as compared to albumin in their study. ${ }^{11}$ However, in another study by Okpa et al who observed decreased serum protein level in HIV patients in their study. ${ }^{12}$ Guardia JA et al observed mean value of serum globulin in his study was $3.1 \mathrm{gm} \% .13$ In contrary Shingdang J et al observed decrease in serum total protein, albumin, globulin but high albumin: globulin ratio. ${ }^{14}$ Jemikalajah JD et al observed increased serum protein, albumin, globulin all with decreased albumin and globulin ratio as compared to control.15 Guenter $\mathrm{P}$ et al observed decreased serum albumin and weight loss related to CD4 counts. ${ }^{16}$ Similarly, in our study we found albumin and globulin ratio altered less than 1 in majority (4: 1) of cases with CD4 less than 200/cc as compared to CD4 more than $200 / \mathrm{cc}$ where alb: glb ratio altered marginally with the ratio of 7:8. Similar observation found by IM Jackson et al, where levels of hypoalbuminaemia decreased with increased CD4 count. ${ }^{17}$ Ikekpeazu Ebele et al observed decreased CD4 count with decreased albumin level. ${ }^{10}$ Oluwaseun 0 and his associates did not find any statistically significant difference with changes of CD4 count and serum immunoglobulin level.11 In our study, we shared a relative hyperproteinaemia in HIV seropositive individuals and this hyperproteinaemia was due to relative hyperglobulinaemia occurring in those individuals.

\section{CONCLUSION}

In patients with HIV, serum albumin was decreased, whereas serum globulin increased above normal value in most of the cases resulting in serum protein level that remains apparently in normal range despite much alteration of albumin and globulin ratio. Globulin plays an important part in maintaining oncotic pressure in HIV patients. Serum albumin level less than $3 \mathrm{gm} \%$ would generally have poor prognosis. Hence, serum albumin level can be used as poor prognostic factor. These decreased albumin levels could reflect the poor nutritional status and latent state of chronic diseases evidenced by significant weight loss.

\section{ACKNOWLEDGEMENT}

Thanks to Mr. Santosh Shaw for making this manuscript complete. We also sincerely thank Dr. Abhijit Mukherjee, Assistant Professor, Community Medicine, North Bengal Medical College, without whose help our statistical calculation would remain incomplete.

\section{REFERENCES}

[1] O'bryan T, Olsen C, Ganesan A, et al. Baseline Albumin/Globulin ratio predicted progression to AIDS among person with stage 1 HIV disease in the precombination antiretroviral therapy era. Open Forum Infectious Diseases 2016;3(Suppl 1):1534.
[2] Arinola OG, Salimonu LS, Okiwelu OH, et al. Levels of immunoglobulin classes, acute phase proteins and serum electrophoresis Nigerian infected with Human immunodeficiency virus. European J Scientific Res 2005;7(3):34-44.

[3] Abayomi A, Adomakoh N, Adomakoh S. Responding to the HIV epidemic in the developing world. Capacity building and technology transfer for monitoring with HAART: a Caribbean experience. Afr J Med Med Sci 2006;35 Suppl:19-24.

[4] Olaleye DO, Harry TO, Odaibo GN. The virology and dynamics of the epidemic in Nigeria. In: Adeyi O, Kanki PJ, Odutolu O, et al, eds. Aids in Nigeria: A Nation on the Threshold, Harvard Centre for Population and Development Studies, Cambridge 2006:37-66.

[5] Carl AB, Edward RA, David EB. Plasma proteins. Tietz fundamental of clinical chemistry. $7^{\text {th }}$ edn. Philadelphia: W.B Saunders 2008:294-7.

[6] Patil R, Raghuwanshi U. Serum protein, albumin, globulin levels, and A/G ratio in HIV positive patients. Biomedical \& Pharmacology Journal 2009;2(2):321-5.

[7] Ullrich R, Zeitz M, Heise W, et al. Small intestinal structure and function in patients infected with human immunodeficiency virus (HIV): evidence for HIVinduced enteropathy. Ann Intern Med 1989;111(1):15-21.

[8] Mehta SH, Astemborski J, Sterling TR, et al. Serum albumin as a prognostic indicator for HIV diseases progression. AIDS Res Human Retroviruses 2006;22(1):14-21.

[9] Quesnel CM, Moja P, Lucht F, et al. Is there IgA of gut mucosal origin in the serum of HIV1 infected patients? Gut 1994;35(6):803-8.

[10] Ikekpeazu Ebele JI, Nwosu Nonso C, Neboh Emeka E, et al. Pre-treatment biochemical laboratory values in asymptomatic HIV-sero positive patients: possible predictors of onset of HAART therapy. Biomedical Res 2012;24(1):19-22.

[11] Akinpelu 00, Ova YAA, Arinola OG. Levels of immunoglobulin classes are not associated with severity of HIV infections in Nigerian patients. World Journal of AIDS 2012;2:232-6.

[12] Okpa HO, Oviasu E, Ojogwu LI. Microalbuminuria and its relationship with clinical and biochemical parameters in newly diagnosed HIV patients in a tertiary hospital south Nigeria. World Journal of Medical Sciences 2015;12(2):83-90.

[13] Guardia JA, Buther OC, Bourgignie JS. Oncotic pressure and edema formation in hypoalbuminaemic HIV infected patients with proteinuria. Am J Kid Diseases 1997;30(6):822-8.

[14] Shingdang J, Bot $Y$, Ojo O, et al. Serum albumin/globulin ratio in tuberculosis and HIV patients any relationship? Mycobacterial Diseases 2016;6(1):1000199.

[15] Jemikalajah JD, Adu ME. Assessment of serum proteins in human immunodeficiency virus patients in Auchi, Nigeria. African Journal of Cellular Pathology 2015;5:14-7. 
[16] Guenter P, Muurahainen N, Simons G, et al. Relationship among nutritional status, disease progression and survival in HIV infections. J Acquir Immune Defic Syndr 1993;6(10):11;30-8.
[17] Mrama IJ, Ngeranwa JN, Mburu DN, et al. A prospective study on the changes of clinical values in HIV infected patients attending Kenyatta national hospital comprehensive care center. Journal of AIDS and HIV Research 2018;10(4):56-63. 